\title{
TYPOLOGY OF THE PYRENEAN SPRINGS BASED ON THEIR BIOLOGICAL COMMUNITIES
}

Josep R. Roca' , Marcos del Castillo 2.1

1 Institut d'Investigacions d'Alta Muntanya. Universitat de Barcelona. 25530 Vielha. Spain; ${ }^{2}$ Departament de Biologia Animal, Departament d'Ecologia. Universitat de Barcelona. Diagonal 645. Barcelona. Spain.

Key words: springs, typology, communities

\section{ABSTRACT}

A large group of Pyrenean springs has been studied, both from a biological and physico-chemical point of view. Here we present a cluster analysis of 94 springs according to their faunal and floral composition. This classification allowed the recognition of two principal groups of springs related to their mineral content and the lithology of their areas: one group is characterized by species indicative of hard and calcic bicarbonate waters of the southern part of the Pyrenees, while the other one corresponds to species of high mountain with low or very low mineral content and neutral or slightly acidic character. Within these two main clusters a further distinction can be made between permanent and less stable or fluctuating springs. Then, the species were classified on the basis of their presence on the springs. The resulting groups could be used as indicators of different physico-chemical conditions.
\end{abstract}

\section{INTRODUCTION}

The interest of springs as rather special small aquatic ecosystems, both from an ecological and biogeographical point of view, has been notice by several authors (Margalef, 1983; Nielsen 1950; Odum, 1971; Hynes, 1970; Thienemann, 1925; Brehm, 1950; Lindegaard \& Thorup, 1975; Thorup 1966; Botosaneanu \& Negrea, 1961; Löffler 1964). While accurate geological classifications of springs. exist, the biological or limnological ones are either partial or they are limited in scope to morphological and physiographical characteristics (Bornhauser, 1912; Steinmann, 1907) and cannot encompass the great variety of these environments in a given area.

A first approach to a limnological typology of springs has been carried out by one of the authors (Roca, 1990a), based on the physics and chemistry of Central Pyrenean springs, and it revealed a broad spring spectrum reflecting the complex lithology of that area. In the present study 94 springs are grouped on the bases of their species composition. The resulting group of springs with similar species composition can be compared with those previously established according to their physics and chemistry.

\section{STUDY AREA}

Ninety four spring were selected from a more extensive sampling carried out during the years 1986 and 1987 (Roca, 1990a). They are situated in the Central Pyrenees, in the watersheds of the rivers Noguera Pallaresa, Noguera Ribagorzana, 
Esera and Cinca, which are tributaries of the Ebro River:

The northern part of this area occurs mainly on limstones in the west and on siliceous non-permeable substrates (granites, slates) in the East. The southern part consists of calcareous series and some evaporite rocks, mainly of Triassic origin (Keuper). The altitudes of the springs range from 400 to 2160 meters above sea level.

\section{MATERIAL AND METHODS}

Each spring was visited only once and environmental characteristics such as seasonality (i.e., permanent / seasonal and temporal springs), flow volume and chemical composition were recorded (detailed data can be found in Roca 1990a). The sample of springs is heterogeneous with regard to their structure (boils, channels, small ponds) as well as to their substrate (sediment, gravel, bryophytes, phanerophytes, pebbles). All the combinations between these structures and substrates were included in the sample. The communities were sampled using sives of $100 \mu, 250 \mu$ mesh size. Biological material was fixed and conserved using different thecniches (Lincoln \& Sheals, 1979; Valdecasas \& Baltanas 1989) depending on each taxonomic group.

The SPSS-X software was used to perform an UPGMA cluster analysis of the 94 springs so as to identify those springs characterized by similar species compositions. The original data set with 388 taxa (Roca, 1990b) was reduced twice, first to a subset of 100 taxa, and then to subset of 84 taxa. The two data matrices were analysed independently for the 94 springs. Matrix 2 is formed by a representative sampling of each taxonomic group, with a total of 100 taxa, from which cosmopolitan taxa as well as very rare species have been previously removed in an attempt to follow the most communly accepted procedure used by ecologists to reduce data to a manageable size for multivariate analyses. Typical running water species (most of them plecoptera and ephemeroptera) were removed to for matrix 1 , with a total of 84 taxa.

\section{RESULTS AND DISCUSSION}

The dendrogram of Fig. 1 corresponds to the cluster analysis of matrix 1 . These classifications is clearly chemical, since it reflects the mineral content of water, which is well correleted with the geographic and lithology of the Pyrenees. Springs appear to be grouped according to a gradient of total mineral content, as measured by their conductivities, which range from above $700 \mu \mathrm{S} \mathrm{cm}^{-1}$ (left half of dendrogram) to less $100 \mu \mathrm{S} \mathrm{cm}^{-1}$ (right half of dendrogram). The following groups can be distinguished in this dendogram:

(1) Group I: Springs with high mineral content $\left(>700 \mu \mathrm{S} \mathrm{cm}^{-1}\right)$ and dominance of sulphates and/or chlorides, distributed in the southern Pyrenees (i.e., the marginal sierra) on Keuper outcrops. They are situated at low altitude and show the highest temperatures of all the springs $\left(11\right.$ to $16^{\circ} \mathrm{C}$.).

A summary of their characteristic taxa is shown in Table 1 , column 1 . In general, their fauna is not very diverse. Only a few species of phanerophytes can be considered typical of these springs, while bryophytes have a higher number of characteristics species. Very hard waters (sodium chloride) have very poorly diversified 
communities with clearly halophilous species; these species are also of endorheic ponds (Alonso, 1985).

(2) Group II: Springs with moderate mineral content $\left(300-700 \mu \mathrm{S} \mathrm{cm} \mathrm{cm}^{-1}\right)$, with calcium and bicarbonate waters, distributed in the calcareous Pyrenees. Many of them are karstic (Roca 1990a) with temperatures ranging from 7 to $11^{\circ} \mathrm{C}$. The species assembleges of their biological communities are clarly defined (Table 1, column 2).

(3) Group III: Springs with low mineral content $\left(100-300 \mu \mathrm{S} \mathrm{cm}^{-1}\right)$, with calcium and sulphate waters, occuring at high altitudes, mainly on graphite slates. Their temperature is low $\left(5-10^{\circ} \mathrm{C}\right)$, and they have high levels of dissolved oxygen. Table 1 , column 3 , lists the taxa defining this group of springs.

(4) Group IV: Springs with very low mineral content $\left(0-100 \mu \mathrm{S} \mathrm{cm}{ }^{-1}\right)$, with calcium and sodium bicarbonates and neutral (7 to 7.3) or sligthly acidic (6-7) pH values. They occur at high altitudes on siliceous rocks (granites). Their temperature is low $\left(1\right.$ to $7^{\circ} \mathrm{C}$.) and their oxygen concentration is high. They are characterized by a large size and a high speed of flow. Their communities are formed by rather specific taxa, which are rarely found in other types of springs (Table 1, column 4). There is a dominance of bryophytes over macrophytes, because of the more efficient absortion of $\mathrm{CO}_{2}$ by bryophytes, which is the main source of $\mathrm{C}$ in acidic waters (Bain \& Proctor, 1980; Peñuelas, 1985; Martinez-Abaigar, 1989). Most of the bryophytes are obligate aquatic species with a clear trend to rheophily (Vitt \& Glime 1984). The speed of flow, temperature and $\mathrm{pH}$ are all very fluctuating because of the melting and freezing cycles, typical of 'high mountains. These unstable environments are occupied by a cosmopolitan biota. Algae are the only primary producers (Margalef, 1948).

The dendrogram of Fig. 2 can be interpreted in physical terms. The first main cluster (I) contains fluctuating seasonal springs, eutrophic springs with periods of drought, and spring with extreme salinity values; the second cluster (II) is composed of stable permanet springs. This same division can be observed in the former dendrogram (Fig. 1) within the large group of calcium bicarbonate springs (Ila and Ilb).

Within group II two subgroups can be iurther distinguished:

(1) Group lla consists of low-flowing and calcium bicarbonate uprings with an important development of macropyte. Taxa indicative of low-flowing springs are noted with an "in table 1.

(2) Group Ilb includes springs with high and very high speed of flow. This group is heterogeneous in mineral content, although calcium bicarbonate waters are dominant. Taxa indicative of high-flowing springs are noted with * in Table 1.

Macrophytes in the fastest waters make serve as a refugium against the current for many organisms, which reach their highest diversity there. Permanent spring with moderate or lowing flowing rates have a great constancy in flow, temperature and other variables, allowing the development of a mosaic of communities (Margalef 1983) that can shelter faunistic elements with different origin (Hynes, 1970; Thienemann, 1925); for instance one can observe the occurence of subterranean, lotic, lentic and stenoic species segregated in different habitats within these springs.

The most fluctuating springs (the seasonal and temporal ones) usualy show periods of extreme hydrological conditions (Roca 1990a) as well as a trend to eutrophication. Fluctuations of the hydrological regime favour the development of a plocon of chloroficees an acelerates the nutrient cylcle (Roca 1990b). Organic matter of allochthonous origin accumulates in seasonal stagnant springs because of incomplete decomposition, and its excess produces chemical anomalies in water (i.e., 
high levels of sulphates and nitrates Roca 1990a). Sometimes eutrophy is maintained or even originated by cattle frequentation. This situation is generaly detected by a great increase of nitrate compound (Roca 1990a). Other sources of eutrophication are uncontrolled dumps from farms and tourists (Roca 1990a). Temporal springs with a clear interrumption of a flow do not allow the development of macrophytes; only some species of mosses are able to tolerate drought (Mniobryum delicatulum, Eucladium verticillatum, Philonotis calcarea) (Roca 1990b). Mosses constitute the only habitat with a relative richness of animals (e.g., some nematodes, oligochaetes, and even a few trichopters). The sediment of these springs is extremly poor on species, which are limited to a few nematodes, oligochaetes and ostracodes (Roca 1990b).

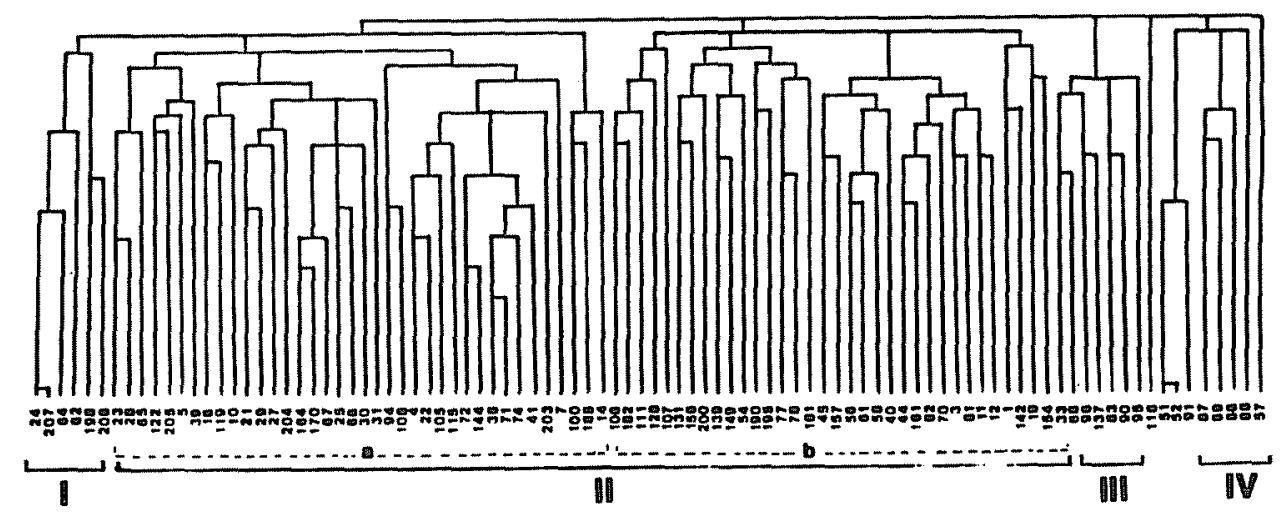

Figure 1. Dendogram of the 94 springs, based on 84 taxa, using the Jaccard similarity coefficent.

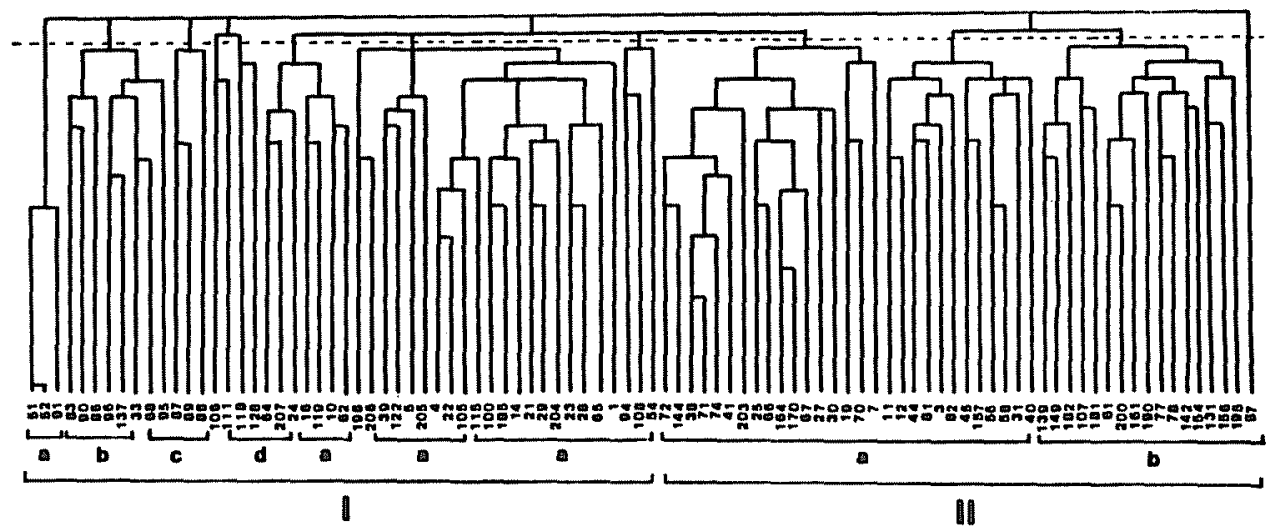

Figure 2. Dendogram of the 94 springs based on 100 taxa, using the Jaccard similarity coefficient. The following correspondences are observed between this dendogram and that of Figure 1: Groups $l a=I I ;|l b=I I| ;|c=I V ;| d=I$. 


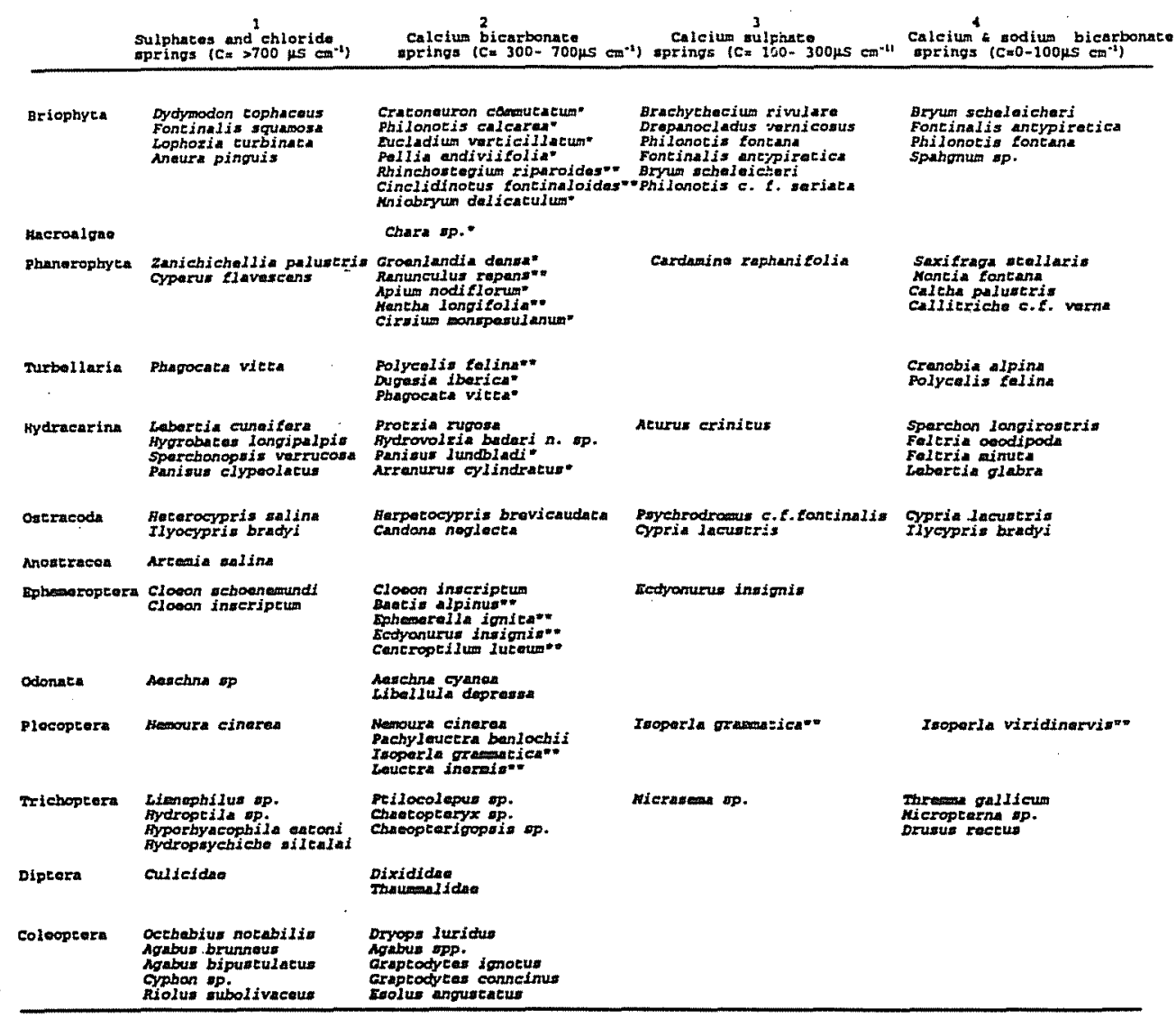

Table 1. Characteristic taxa associated to each group of springs. The " signals taxa of low-flowing water and "* those indicative of high-flowing water.

\section{CONCLUSIONS}

This study has revealed a remarkable diversity of types of springs: Two main groups can be recognized in the cluster analyses of the Central Pyrenean springs. One can be related to the mineral content of water and the other one to the hydrological regimes of the springs. This first division coincides with the physicochemical typology of Pyrenean springs presented by Roca (1990a).

The first of these two groups could be subdivided into four groups (fig. 1):

(1) Springs with very high mineral content and a high proportion of sulphates and/or chlorides (group I).

(2) Springs with moderate mineral content and with calcium bicarbonate waters (group II).

(3) Springs with low mineral content and calcium sulphate waters (group III).

(4) Springs with a very low mineral content, with sodium and calcium bicarbonate waters of neutral or sligthly acidic pH (group IV). 
Because of the dominance of calcareous substrates in the Pyrenees the group II is the most widespread in this region, and consequently its biota can be preciced in grat detail.

The second main group could be subdivided into (fig. 2):

(1) a group of seasonal springs with great variations of flow and other parameters, which include springs with an extreme mineral content and springs with periods of complete drought (group I).

(2) a group of permanent springs with slight fluctuations of flow, basically formed by calcium bicarbonate springs (group II).

While the first component (mineral content) of this classification seem to play an important role in the composition of communmities, the second one (hydrological regime) acts at the level of community structure. Studies of diversity of diatom assemblages reached this same conclusion (Sabater \& Roca 1990).

Spring communities have a great importance in fluvial systems keeping a high diversity of species in them, specially in high mountain and arid regions. Further functional studies of spring ecosystems could be very useful to unify ecological models of fluvial systems.

\section{AKNOWLEDGEMENTS}

This work was partially supported by a CICYT project (ref. PB87-0318). One of the authors (Roca) was supported by a doctoral grant (a FPI from the MEC).

\section{REFERENCES}

Alonso, M. 1985. Las lagunas de la España peninsular: taxonomía, ecología y distribución de los cladoceros. Tesis Doct. Depto. Ecología. Universidad de Barcelona.

Bain, J.T. \& Proctor, M.C.F. 1980. The requerement of aquatic bryophytes for free carbon dioxide as an inorganic carbon source: some experimental evidences. New. Phytol., 86:393-400.

Bornhauser, K. 1912. Die Tierwelt der Bäche und Quellen in der Umgebung Basels. Int. Rev. ges. Hydrobiol. Biol. Suppl. 5:1-90.

Botosaneanu, L. \& Negrea, S.T. 1961. Une Oasis aquatique à faune relique dans la Plaine du Danube inférieur. Hydrobiologia, 18:199-218.

Brehm, V. 1950. Apostillas zoogeográficas a varios trabajos del Profesor Gauthier, con un apéndice sobre las características biogeográficas de algunos grupos de organismos dulceacuícolas. Publ. Inst. Bio. Apl., VII:83-130.

Lincoln, R.J. \& Sheals, J.G. 1979. Invertebrate Animals. Collection \& Preservation. British Museum (Natural History), London.

Lindegaard, C. \& Thorup, J. 1975. The invertebrate fauna of the moss carpet in the Danish spring Raunkilde. Arch. Hydrobiol. 75:109-139.

Löffler, H. 1964. Beitrag zur Kenntnis der Entomostraken burgenländisches Brunnen und Quellen (Südl. Burgenland) Wiss. Arb. Burgenland 31:156- 169.

Hynes, H.B.N. 1970. The ecology of Running waters. Liverpool University Press, Liverpool.

Margalef, R. 1948. Flora y fauna y comunidades bióticas de las aguas dulces del 
Pirineo de la Cerdaña. Monograf. Estación de Estudios Pirenaicos, 11:1-226 Margalef, R. 1983. Limnología. Omega, Barcelona. 1010 pp.

Martinez-Abaigar, J. 1989. Briofitos acuáticos del Rio Irequa (La Rioja). Estudio florístico, ecológico y ecofisiológico. Respuestas a la contaminación orgánica. Tesis Doctoral. Universidad de Navarra.

Nielsen, A. 1950. On the zoogeography of springs. Hydrobiologia, 2:313-321.

Odum, E.P. 1971. Fundamentals of Ecology. Third edition. W.B. Saunders company, Philadelphia. $546 \mathrm{pp}$.

Peñuelas, J. 1985 Briofits i fanerògames com a invasors de les aigües dolçes. Distribució, pigments, fonts de carboni i l'obstacle dels espais aèris. Tesis Doctoral. Universitat de Barcelona.

Roca, J.R. 1990a. Tipologia físico-quimica de las fuentes de los Pirineos Centrales: Síntesis regional. Limnetica, 6:57-78.

Roca, J.R. 1990b. Poblamiento de las fuentes de los Pirineos Centrales: Faunística y Ecología. Tesis Doctoral. Universitat de Barcelona.

Steinmann, A. 1907. Die Tienwelt der Gebirgsbäche. Eine Faunistisch-biologische Studie. Annls. Biol. lacustre 2:30-150.

Sabater, S. \& Roca, J.R. 1990. Some factors affecting distribution of diatom assemblages in Pyrenean springs. Freshwater Biology, 24:493-507.

Thienemann, A. 1925. Die Quelle. Eine limnologische Einführung Die Binnegewässer. Mitteleuropas.

Thorup, J. 1966. Substrate type and its value as a basis for the delimetation of bottom fauna communities in running waters. Spec. Publs Pymatming Lab. Fld. Biol. 4:59-74.

Valdecasas, G. \& Baltanás, A. 1989. A note on the use of Angelier's fluid for Freshwater invertebrates. Arch. Hydrobiol, 115 (2):313-316.

Vitt, D.H. \& Glime, J.M. 1984. The structural adaptations of aquatic Musci. Lindbergia, 10:95-110. 